\title{
Web-mediated Counseling Relationship in Support of the New Sexuality and Affectivity During the COVID-19 Epidemic: A Continuum Between Desire and Fear
}

\author{
Giuseppe Marano $^{1,2} \cdot$ Gianandrea Traversi $^{3} \cdot$ Marianna Mazza $^{1}$ (1)
}

Received: 11 July 2020 / Revised: 7 December 2020 / Accepted: 11 December 2020 / Published online: 21 January 2021

(c) The Author(s), under exclusive licence to Springer Science+Business Media, LLC part of Springer Nature 2021

A new coronavirus, SARS-CoV-2, has triggered the global emergency of the World Health Organization causing symptoms ranging from the common cold to serious respiratory diseases, and it is responsible for the current COVID-19 epidemic. Older people and those with other underlying diseases, such as hypertension, heart problems (Marano et al., 2009, 2011b; Mazza, Marano, Lai, Janiri, \& Sani, 2020c), neurological diseases (Marano et al., 2011a), diabetes, and immunosuppressed patients are more likely to develop the illness in serious forms. This totally sudden and unexpected condition risks not only to worsen the conditions of care, but also to lead the social fabric to serious psychic suffering, or to significantly aggravate people who are already affected by psychiatric disorders or psychological problems (Marano et al., 2020; Mazza et al., 2020a; Mazza, Marano, Janiri, \& Sani, 2020b).

The epidemic has deprived us of freedom and intimacy (Jacob et al., 2020). During the pandemic, there are several aspects that may impact on sexual activity such as time spent together, lesser work burden, need of opportunities for recreation, parenting obligations, possibility of interpersonal conflict, lack of privacy, and distress (Döring, 2020).

Arafat, Alradie-Mohamed, Kar, Sharma, and Kabir (2020) in a cross-sectional study conducted among individuals of three southeast Asian countries (Bangladesh, India, and Nepal) found that $60.1 \%$ of the sample reported that they

Marianna Mazza

mariannamazza@hotmail.com

1 Institute of Psychiatry and Psychology, Department of Geriatrics, Neuroscience and Orthopedics, Fondazione Policlinico Universitario A. Gemelli IRCCS, Università Cattolica del Sacro Cuore, Largo A. Gemelli 8, 00136 Rome, Italy

2 U.P. ASPIC Università Popolare del Counseling, Rome, Italy

3 Department of Science, University of Rome "Roma Tre", Rome, Italy were not sexually active during the period of social distancing and $45 \%$ of the participants described that the quarantine had affected their sexual life. There is a difference in the management of sexual activity between men and women: less sexual activity has been observed in female subjects, elderly people, and unmarried individuals (Arafat et al., 2020).

A survey on an Italian population focusing on changes in sexuality and quality of couple relationship during COVID19 lockdown found in female participants a decrease in pleasure, satisfaction, desire, and arousal. The main reasons behind the changes in sexuality in women appear to be worry, lack of privacy, and stress. Even when participants seemed to show high levels of resilience, the negative aspects of lockdown could affect their quality of sexual life (Panzeri, Ferrucci, Cozza, \& Fontanesi, 2020). Potentially, the more time available might lead couples to reconnect at an intimate level and to improve their sexuality. However, it has been noticed by Cito et al. (2021) that the majority of quarantined subjects experienced reduced number of sexual intercourse per week, with poor household privacy and lack of psychological stimuli. Another survey conducted during COVID-19 outbreak in India found that qualities of sexual life, sex hygiene, and desire for parenthood in female respondents were higher as compared to male respondents (Mahanty, Kumar, \& Mishra, 2020). Similar results have been reported with a great influence of COVID-19 pandemic on the quality of sexual life and frequency of intercourse among Polish women (Fuchs et al., 2020). Besides, a Turkish study has stressed that the pandemic is associated with decreased desire for pregnancy, decreased female contraception, and increased menstrual disorders in females (Yuksel \& Ozgor, 2020). In the U.S., it has been observed that among individuals in relationships, about $34 \%$ reported some degree of conflict with their romantic partners due to the spread of COVID-19 and its related restrictions (Luetke, Hensel, Herbenick, \& Rosenberg, 2020).

The pandemic imposes new lifestyles that upset sentimental and sexual relationships by relocating them within 
a screen oxygenated by chat where the Web takes the place of the partner's body (Tonioni et al., 2018). The use of the net as an affective and sexual substitute could also generate some form of craving. The risk of this alternative intimacy, if persisting over time, is that it can be converted into a form of extimacy (Lacan, 1964) by bringing together the concept of extraneousness and intimacy, condensing them into one word.

It is necessary and possible to discover or rediscover new ways of showing affection, love, and closeness, but there are limitations in sexual life that can leave a sense of loss and a clear perception of sacrifice. Meeting the body and desire of the other can make the experience of emotional reciprocity by directing the affective and sexual lines toward a single person, but this meeting can also be a place of loss or encroachment, or even a need for recognition and enhancement, or finally to be part of the extended social gaze.

It is not always true that forced presence diminishes desire and that, on the contrary, distancing strengthens it: desire and fear in the COVID era become the dialectic poles of the mind. On the one hand, one can be driven to action as a Bionian form of defense (Bion, 1962); on the other, one can escape from desire until it is neutralized. Libidinal introversion risks of being fatally reactivated over time; in fact, the danger of increased intra-family gender violence is reported in the quarantine literature (Chynoweth, Amsalu, Casey, \& McGinn, 2018; Mazza et al., 2020b; Tang, Gaoshan, \& Ahonsi, 2020).

Impulsiveness can become so strong that it cannot be controlled by overwhelming the thought and driving to an unthought action without any real connotation of an affective character, but as an acting-out, a regulating act of the intrapsychic tension moving it to the external world (Blos, 1993). The virus can trigger the fear of loneliness, pushing the isolated subject to reconnect with old, negative or unsatisfactory old relationships, or even throwing it carelessly headlong into others that have just started. Conversely, the desire for proximity and exchange can generate fear of contagion and consequently conduct to the point that all involvement is renounced, investments on external objects are abandoned, so that the death drive meets narcissism (Freud, 1920) and the subject ends up in phobia of contagion and anguish. Coexistence with the virus becomes problematic when fear turns into defense and kills desire, which can no longer be renewed and transformed through subjective invention.

The World Health Organization has recognized the importance of a healthy and satisfying sexuality for the complete well-being of the person. According to our clinical practice, it is essential at the time of the Coronavirus, when relationships are bodiless, to plan Web-mediated person-centered counseling interventions and to hold people's experiences by promoting self-awareness and self-efficacy, trying to invest the unexpressed sexual energy into something constructive.

\section{References}

Arafat, S. M. Y., Alradie-Mohamed, A., Kar, S. K., Sharma, P., \& Kabir, R. (2020). Does COVID-19 pandemic affect sexual behaviour? A cross-sectional, cross-national online survey. Psychiatry Research, 289. https://doi.org/10.1016/j.psychres.2020.113050.

Bion, W. R. (1962). Learning from experience. London: William Heinemann.

Blos, P. (1993). L'adolescenza come fase di transizione. Aspetti e problemi del suo sviluppo. Retrieved June 1, 2020 from http://books.google.com/books?hl=it\&lr=\&id=4ArunxblMq EC\&pgis $=1$.

Chynoweth, S. K., Amsalu, R., Casey, S. E., \& McGinn, T. (2018). Implementing sexual and reproductive health care in humanitarian crises. The Lancet, 391, 1770-1771. https://doi.org/10.1016/ S0140-6736(18)30803-1.

Cito, G., Micelli, E., Cocci, A., Polloni, G., Russo, G. I., Coccia, M. E., et al. (2021). The impact of the COVID-19 quarantine on sexual life in Italy. Urology, 147, 37-42. https://doi.org/10.1016/j.urolo gy.2020.06.101.

Döring, N. (2020). How is the COVID-19 pandemic affecting our sexualities? An overview of the current media narratives and research hypotheses [Commentary]. Archives of Sexual Behavior, 49, 2765-2778. https://doi.org/10.1007/s10508-020-01790 -Z.

Freud, S. (1920). Al di là del principio di piacere. Torino: Bollati Boringhieri. Retrieved June 22, 2020 from https://www.ibs.it/ al-di-del-principio-del-libro-sigmund-freud/e/9788833900551.

Fuchs, A., Matonóg, A., Pilarska, J., Sieradzka, P., Szul, M., Czuba, B., \& Drosdzol-Cop, A. (2020). COVID-19 social distancing and sexual activity in a sample of the British public. International Journal of Environmental Research and Public Health., 30(17), 7152. https://doi.org/10.3390/ijerph17197152.

Jacob, L., Smith, L., Butler, L., Barnett, Y., Grabovac, I., McDermott, D., et al. (2020). Challenges in the practice of sexual medicine in the time of COVID-19 in the United Kingdom. Journal of Sexual Medicine, 17, 1229-1236. https://doi.org/10.1016/j. jsxm.2020.05.001.

Lacan, J. (1964). Libro 11: I quattro concetti fondamentali della psicoanalisi. Torino: Einaudi.

Luetke, M., Hensel, D., Herbenick, D., \& Rosenberg, M. (2020). Romantic relationship conflict due to the COVID-19 pandemic and changes in intimate and sexual behaviors in a nationally representative sample of American adults. Journal of Sex and Marital Therapy, 46, 747-762. https://doi.org/10.1080/00926 23X.2020.1810185.

Mahanty, C., Kumar, R., \& Mishra, B. K. (2020). Analyses the effects of COVID-19 outbreak on human sexual behaviour using ordinary least-squares based multivariate logistic regression. Quality \& Quantity. https://doi.org/10.1007/s11135-020-01057-8.

Marano, G., Gaetani, E., Gasbarrini, A., Janiri, L., Sani, G., \& Mazza, M. (2020). Mental health and counseling intervention for hereditary hemorrhagic telangiectasia (HHT) during the COVID-19 pandemic: Perspectives from Italy. European Review for Medical and Pharmacological Sciences, 24(19), 10225-10227.

Marano, G., Harnic, D., Lotrionte, M., Biondi-Zoccai, G., Abbate, A., Romagnoli, E., \& Mazza, M. (2009). Depression and the cardiovascular system: Increasing evidence of a link and therapeutic 
implications. Expert Review of Cardiovascular Therapy, 7, 1123-1147. https://doi.org/10.1586/erc.09.78.

Marano, G., Traversi, G., Bria, P., Mazza, S., \& Mazza, M. (2011a). Primary cerebral blood flow deficiency and Alzheimer's disease: Shadows and lights. Journal of Alzheimer's Disease, 23, 375-389. https://doi.org/10.3233/JAD-2010-090700.

Marano, G., Traversi, G., Romagnoli, E., Catalano, V., Lotrionte, M., Abbate, A., et al. (2011b). Cardiologic side effects of psychotropic drugs. Journal of Geriatric Cardiology, 8, 243-253. https ://doi.org/10.3724/SP.J.1263.2011.00243.

Mazza, M., Marano, G., Antonazzo, B., Cavarretta, E., Di Nicola, M., Janiri, L., et al. (2020a). What about heart and mind in the Covid-19 era? Minerva Cardioangiologica, 5, 8-9. https://doi. org/10.23736/S0026-4725.20.05309-8.

Mazza, M., Marano, G., Janiri, L., \& Sani, G. (2020b). Managing bipolar disorder patients during COVID-19 outbreak. Bipolar Disorders, 22, 870-871. https://doi.org/10.1111/bdi.13015.

Mazza, M., Marano, G., Lai, C., Janiri, L., \& Sani, G. (2020c). Danger in danger: Interpersonal violence during COVID-19 quarantine. Psychiatry Research, 289. https://doi.org/10.1016/j.psych res.2020.113046.

Panzeri, M., Ferrucci, R., Cozza, A., \& Fontanesi, L. (2020). Changes in sexuality and quality of couple relationship during the COVID-19 lockdown. Frontiers in Psychology, 11, 565823. https://doi. org/10.3389/fpsyg.2020.565823.

Tang, K., Gaoshan, J., \& Ahonsi, B. (2020). Sexual and reproductive health (SRH): A key issue in the emergency response to the coronavirus disease (COVID-19) outbreak. Reproductive Health, 17(1), 1-3. https://doi.org/10.1186/s12978-020-0900-9.

Tonioni, F., Mazza, M., Autullo, G., Pellicano, G. R., Aceto, P., Catalano, V., et al. (2018). Socio-emotional ability, temperament and coping strategies associated with different use of Internet in Internet addiction. European Review for Medical and Pharmacological Sciences, 22(11), 3461-3466. https://doi.org/10.26355/eurre v_201806_15171.

Yuksel, B., \& Ozgor, F. (2020). Effect of the COVID-19 pandemic on female sexual behavior. International Journal of Gynecology and Obstetrics, 150(1), 98-102. https://doi.org/10.1002/ijgo.13193.

Publisher's Note Springer Nature remains neutral with regard to jurisdictional claims in published maps and institutional affiliations. 